\title{
PEMANFAATAN POTENSI ANGIN LAUT PENGGERAK MESIN PERAHU NELAYAN PENGGANTI MESIN BERTENAGA MINYAK
}

\author{
Budi Prijo Sembodo, Rony Haendra Fora dan Sri Widyastuti*)
}

\begin{abstract}
Wind Power Plants convert wind energy into electrical energy using wind turbines or windmills. The problem is when in season Mitra wind / west season, fishermen catching crabs can not directly capture crabs. The process can wait for days, until the right time to spread the net. When should wait for the weather improves fuel becomes a major problem. Fishermen do not have the ability to purchase fuel in bulk. Results KKN PPM Theme : minimation fuel problem , known as fossil fuels, the use of the traditional mindset change boat engine oil into the engine fueled with energy saving environmentally friendly energy alternatives that are cheaper, achieved education for sustainable development, economic improvement occurred residents by selling the products of wind energy boat engine. Method in empowerment, operational steps to correct the problem, the volume of work in the form of JKEM and the total volume of work
\end{abstract}

Kata kunci : mengare, tenaga angin, turbin angin

\section{PENDAHULUAN}

Energi angin merupakan salah satu potensi energi terbarukan yang dapat memberikan kontribusi signifikan terhadap kebutuhan energi listrik domestik, khususnya wilayah terpencil. Pembangkit energi angin yang biasa disebut Pembangkit Listrik Tenaga Bayu (PLTB) atau Sistem Konversi Energi Angin (SKEA) ini bebas polusi dan sumber energinya yaitu angin tersedia di mana pun. Pembangkit ini dapat menjawab masalah lingkungan hidup dan ketersediaan sumber energi.

Dibandingkan dengan sumber energi alternatif lainya ekstraksi energi dari angin memiliki carbon footprint yang relatif rendah. Carbon footprint yang dimaksud di sini adalah emisi $\mathrm{CO} 2$ yang dihasilkan dari keseluruhan proses produksi turbin sampai dengan operasi pemanfaatan sumber energi tersebut. Untuk Sistem Konversi Energi Angin (SKEA) carbon footprint meliputi proses pembuatan turbin, generator, konstruksi, dan operasi dari SKEA. Perbandingan carbon footprint dari SKEA dibandingkan dengan sistem konversi energi lainya

\section{METODA PELAKSANAAN}

Mekanisme pelaksanaan kegiatan KKN PPM sebagai berikut : survey lapangan, negosiasi mitra, penyusunan proposal, pengurusan perijinan, pembekalan, pelatihan mahasiswa, sosialisasi dan pelatihan kepada kelompok sasaran tentang pembuatan dan penerapan di lapangan : Kincir/turbin angin yang menggerakkan generator. Aki sebagai penyimpanan energi listrik serta Motor DC sebagai penggerak / pendorong perahu untuk melaju.

Materi Persiapan dan Pembekalan KKN PPM kepada Mahasiswa meliputi Pembuatan Kincir/turbin angin yang menggerakkan generator dan Cara pengoperasian dan perawatan peralatan untuk pembuatan Motor DC sebagai penggerak / pendorong perahu. Seluruh materi pembekalan dan pelatihan dibuat secara khusus sebagai modul

Langkah-langkah dalam bentuk program yang akan dilaksanakan untuk mencapai hasil yang diharapkan dari tema KKN PPM yang diajukan adalah :

a. Kegiatan partisipasif dari kelompok sasaran pra program adalah keikut sertaan pada pencarian data input untuk penyusunan program KKN PPM. Dalam hal ini masyarakat / kelompok sasaran dapat mengikuti sosialisasi program dan memberikan data (jawaban) yang dipergunakan untuk kepentingan analisis lapangan pada kegiatan survey awal.

b. Partisipasif pada kegiatan pelaksanaan KKN PPM, masyarakat / kelompok sasaran diharapkan berperan aktif pada pembuatan Kincir/turbin angin yang menggerakkan generator, menentukan posisi pada perahu untuk dijadikan tempat pemasangannya.

c. Partisipasi kelompok sasaran untuk mengikuti pelatihan pembuatan Kincir/turbin angin yang menggerakkan generator,

*) Desen Teknik Elektro dan Teknik Lingkungan Universitas PGRI Adi Buana Surabaya 
d. Partisipasi kelompok sasaran sebagai sentra pembuatan Kincir/turbin angin yang menggerakkan generator,

e. Partisipasi kelompok sasaran untuk membuat laporan dan membantu pelaksanaan monitoring dari tim penyelenggara program KKN PPM

\section{HASIL PELAKSANAAN}

Kegiatan KKN-PPM dilaksanakan se- lama1bulan mulai tanggal 27 September s/d 28 Oktober di Desa Kramat Kecamatan Bungah Kabupaten Gresik. Mahasiswa peserta KKN berjumlah 46 mahasiswa.

Program pemanfaatan potensi angin laut untuk penggerak mesin perahu nelayan sebagai pengganti mesin bertenaga bahan bakar minyak di Desa Kramat Kecamatan Bungah kabupaten Gresik merupakan upaya untuk mengatasi biaya operasional pembelian bahan bakar untuk mesin perahu yang tinggi dengan memanfaatkan tenaga angin yang melimpah. dengan mengganti mesin berbahan bakar minyak, maka digunakan motor elektrik untuk pendorong perahu yang sumber energinya dari aki.

Sedangkan untuk pengisi energi aki menggunakan pembangkit listrik hasil konversi dari energi angin. Hal ini akan otomatis menghilangkan biaya pembelian bahan bakar bensin, dimana energi angin di daerah pesisir pantai ini sangat melimpah.

Adapun deskripsi kegiatan adalah sebagai berikut:

\section{a. Persiapan}

Persiapan dilakukan sebagai bentuk pembekalan kepada mahasiswa setelah mendapatkan data-data dari hasil survey. Pembekalan berupa : pembekalan institusi yang mempersiapkan mahasiswa untuk dapat memahami infrastruktur masyarakat desa serta perilaku kehidupan masyarakat desa, selanjutnya dilakukan pelatihan tentang pemanfaatan potensi angin laut untuk penggerak mesin perahu nelayan sebagai pengganti mesin bertenaga bahan bakar minyak.

\section{b. Pelaksanaan}

1. Sosialisasi pemanfaatan potensi angin laut untuk penggerak mesin perahu nelayan sebagai pengganti mesin bertenaga bahan bakar minyak kepada warga masysrakat desa Kramat

2. Perakitan mesin perahu tenaga angin

3. Uji coba mesin perahu tenaga angin ke perahu nelayan
4. Perakitan turbin
5. Uji coba turbin angin
6. Pemasangan mesin perahu tenaga angin ke perahu nelayan

Dari keseluruhan rencana program dan program bantu, semua program dapat dilaksanakan dengan baik dan lancar, terutama program inti yang menjadi tema kegiatan yaitu "Pemanfaatan Potensi Angin Laut untuk Penggerak Mesin Perahu Nelayan Sebagai Pengganti Mesin Bertenaga Bahan Bakar Minyak".

\section{c. Faktor Penghambat}

1. Keterbatasan waktu yang dimiliki oleh mahasiswa dan warga untuk memberikan sosialiasi

2. Faktor akomodasi yang menghambat setiap kegiatan, yaitu kurangnya transportasi mahasiswa dalam melakukan setiap kegiatan

3. Kurang adanya kerja sama dari beberapa perangkat desa yang mengakibatkan kurang optimalnya mahasiswa mensosialisasikan setiap kegiatan yang dilakukan

4. Terbenturnya jadwal kegiatan dengan jadwal warga, yaitu minimnya warga yang mempunyai waktu luang di pagi sampai sore hari, sehingga kurang menyeluruh dalam pemberdayaannya.

5. Turbin angin

Turbin angin dipasang di area pertambakan dekat dengan balai nelayan. Ketinggian turbin angin 9 meter disesuaikan dengan kondisi lingkungan. Dari hasil pengamatan, turbin angin berputar normal sore hari kira-kira mulai pukul 14.00 sampai dengan 21.30 (kurang lebih 7 jam berputar). Proses pengisian aki dengan menggunakan kontrol aki 10 Ampere dibutuhkan waktu 12 jam pada kondisi aki kosong sampai terisi penuh. Namun karena masih terdapat sisa pengisian, hanya dibutuhkan waktu kurang lebih 6 jam proses pengisian ulang. Untuk mengatasi hal tersebut di sediakan 1 buah aki sebagai cadangannya.

6. Mesin Perahu Listrik

Operasional mesin perahu listrik dilakukan oleh nelayan pada saat melaut yakni pukul 19.00 sampai dengan pukul 05.00, menempuh jarak kira-kira 30-60 menit sesuai dengan tujuan. Setelah sampai area yang dituju untuk mencari ikan, mesin 
dimatikan dan di nyalakan kembali apabila akan mendarat. Total waktu penggunaan mesin perahu listrik kurang lebih 3 jam. Pada saat uji coba yang pertama karena ketidaktahuan nelayan dalam mengoperasikan mesin perahu listrik, kapasitor terbakar. Setelah diadakan perbaikan serta pengarahan cara mengguanakan mesin perahu listrik kepada para nelayan, mesin tidak lagi mengalami kendala. Saat para nelayan istirahat, aki yang dipakai perlu di lakukan pengisian atau charge. Aki cadangan bisa dimanfaatkan apabila para nelayan akan melaut lagi.

7. Respon Nelayan

Sebagian besar para nelayan cukup antusias terkait dengan penggunaan perahu tenaga listrik dalam rangka hemat energi, namun karena harga mesin perahu listrik dan turbin angin mahal dan tidak terjangkau oleh para nelayan di desa kramat (mengare) kecamatan gresik dibandingkan dengan mesin bensin yang jauh lebih murah, para nelayan hanya ingin mencoba mengoperasikan mesin bantuan saja belum ada niatan untuk memesan dan mengembangkannya. Padahal apabila mesin perahu listrik beroperasi sesuai uji coba maka untuk jangka panjang para nelayan tidak mengeluarkan biaya pembelian bahan bakar maupun perawatan, hanya kurang lebih 3 tahun dana yang dikeluarkan adalah pembelian aki baru. Dalam jangka 5 tahun secara perhitungan ekonomis perahu listrik ternyat lebih hemat.

\section{Rencana Keberlanjutan Program}

Rencana keberlanjutan program untuk kegiatan KKN-PPM 2013 ini adalah:

1) Memperluas lingkup lokasi KKN-PPM

2) Menjadikan desa Kramat sebaai desa binaan KKN PPM

\section{KESIMPULAN DAN SARAN}

Seluruh perencanaan program baik program utama dan program pendukung 95 $\%$ telah dilaksanakan dengan baik dan lancar tanpa hambatan berat yang mengganggu berjalannya program ini. Segala permasalahan dan keterbatasan yang timbul adalah kewajaran dan dapat dengan segera ditemukan jalan keluarnya. Hal yang terpenting adalah mahasiswa KKN - PPM 2013 dapat mengambil pelajaran dari seluruh permasalahan dalam melaksanakan program kerja terkait sasaran di tengahtengah masyarakat yang dirasakan masing - masing individu. Tidak selamanya niat yang baik dengan cara yang baik dapat diterima dengan baik di masyarakat. Kegiatan KKN - PPM 2013 ini memiliki sasaran yaitu: nelayan, warga masyarakat desa Kramat,siswa-siswi SD/MI desa Kramat, pengusaha terasi,krupuk dan ikan asin.

Kekompakan dari beberapa bagian masyarakat dapat memajukan Desa Kramat Kecamatan Bungah Kabupaten Gresik Propinsi Jawa Timur dalam berbagai bidang.

\section{DAFTAR PUSTAKA}

Alamsyah,Hery. 2009. Pemanfaatan Turbin Angin Dua Sudu Sebagai Penggerak. Fakultas Teknik Universitas Negeri Semarang. Semarang

http://www.bappekab.Gresikkab.go.id/?file=03-doc-rencana/rtrw.htm

http://www.eastjava.com/plan/banner/Gresik.jpg

http://www.jatimprov.go.id/index.php?option=com content\&task=view\&id=4523\&ltemid=2

Jajuli, Holid. 2009. Merancang Alat Pembangkit Listrik Tenaga Angin Sederhana. Institut Teknologi Bandung Press

Setiono, Puji. 2006. Pemanfaatan Alternator Mobil Sebagai Pembangkit Listrik Tenaga Angin. Teknik Elektro Fakultas Teknik Universitas Negeri Semarang. Semarang

UK Parliamentary Office of Science and Technology, November 2006 